\title{
Fiscal councils' impact on promoting transparency and accountability in public finance management
}

\author{
SANJA BACH, PhD*
}

Preliminary communication**

JEL: E62, G28, H60

https://doi.org/10.3326/pse.44.3.4

\footnotetext{
* The author would like to thank three anonymous referees whose comments and advice greatly improved the quality of the paper, as well as members of eighteen fiscal councils in the EU countries who provided answers to the questionnaire.

** Received: October 19, 2018

Accepted: April 4, 2020
}

\section{Sanja BACH}

Ministry of Finance of the Republic of Croatia, Katančićeva 5, 10000 Zagreb, Croatia

e-mail: sanja.bach@mfin.hr, sanja.bach1@zg.t-com.hr

ORCID: 0000-0002-5484-6402 


\section{Abstract}

This paper addresses two main questions: (1) how far do the activities of fiscal councils in the EU countries help promote transparency and accountability in the management of public finances and (2) how could fiscal councils enhance the impact of those activities? The analysis is based on a questionnaire collected in 2016 from fiscal councils in 18 EU countries. The questionnaire looked at how the councils themselves assessed their impact on the management of public finances, and how they communicated their findings to the wider public. The councils see some benefits of their work; and their monitoring of adherence to fiscal rules and legislative regulation, as well as their warnings about excessive government spending, seem to get noticed in the media. This activity informs the public, and may in turn influence politicians'ratings, thereby helping to contribute to greater accountability in the management of public finances. The paper consequently argues that fiscal councils may promote fiscal transparency and accountability and proposes several ways to enhance the effectiveness of their influence on media.

Keywords: fiscal councils, fiscal transparency, fiscal accountability, fiscal policy communication, media influence

\section{INTRODUCTION}

This paper studies how fiscal councils in selected EU countries influence fiscal transparency and the accountability of politicians for the management of public finances. The question of whether fiscal councils can increase the visibility of compliance with fiscal rules through active communication with the public is important for several reasons. Media, especially digital media, can provide information that has bearing on the political ratings of the individuals and organisations in charge of managing public finances in more or less real time. Owing to competition among media outlets, that information is likely to affect the reputation of politicians responsible for government budgets. ${ }^{1}$

Fiscal councils are independent public institutions whose broad goal is to promote sustainable public finances. They have a mandate to assess fiscal plans, evaluate macroeconomic or budgetary forecasts of fiscal authorities, and make other analyses that may contribute to the public debate on fiscal policy and fiscal transparency (Calmfors and Wren-Lewis, 2010; IMF, 2013). To build their credibility, fiscal councils seek to establish a track record of solid analysis and effective public announcements. ${ }^{2}$ Based on information about government activities, voters and financial markets are better able to assess government's fiscal position, present and future costs and benefits of various tax and expenditure proposals, and the longer-term consequences of fiscal policy on the economy and the society (Kopits and Craig, 1988). This can in principle enhance fiscal accountability, i.e. provide

\footnotetext{
1 "Fiscal councils do not directly affect fiscal policy, their influence hinges importantly on the reputational and electoral impact of their analyses on fiscal policymakers" (Debrun et al., 2013:52).

${ }^{2}$ Transparency refers to the publication of relevant, accessible, timely and accurate information on activities, rules, plans and processes in the budget process (IMF, 2014; 2016; 2019; OECD, 2002; 2013).
} 
incentives for politicians in the executive branch to act more responsibly and face the consequences of poor decisions (OECD, 2002).

This paper uses findings from a questionnaire collected from eighteen fiscal councils in EU countries. The main research question is whether more effective communications of fiscal councils with the public helped to improve fiscal transparency and accountability. The paper finds some limited evidence to support this view.

The next sections will briefly review the literature, presents the data and research methodology, discuss the results and develop arguments for the importance of councils' improved communications with the public.

\section{RELATED LITERATURE}

This paper draws on the rich political economy literature studying the activities of fiscal councils (Schuknecht, 2004; Calmfors and Wren-Lewis, 2010; Wyplosz, 2012; 2015; Debrun et al., 2013; Schick, 2010; 2013). One of the recurring themes is that fiscal councils can improve democratic accountability and discourage opportunistic shifts in fiscal policy, such as pre-electoral spending sprees, by fostering transparency over the political cycle. Through independent analysis, assessments and forecasts, such bodies can raise public awareness about the consequences of certain policy paths, and thereby contribute to a culture of stability in public finances. Fiscal councils can thus raise the reputational and electoral costs of unsound policies and broken commitments. They can also provide valuable direct input in the budget process, such as independent forecasts or assessments of structural fiscal positions, thereby closing technical loopholes that allow governments to circumvent numerical fiscal rules (Debrun et al., 2013, 7-8).

Another recurring theme is that fiscal councils help enhance the transparency and accountability of public finances. By publicly commenting on fiscal policy and analysing government budgets, fiscal councils are prima facie instruments of fiscal transparency. Moreover, given the right conditions, they can generate a positive feedback loop for fiscal transparency: a wider public, better educated in fiscal policy, will demand more and better information on government budgets from public officials. The officials will likely oblige and provide such information for the sake of their own reputation; the councils will process and disseminate it; the public will evaluate their analysis, and so on. In Sweden, for instance, the fiscal council has an explicit mandate to assess the transparency of budget documents.

The more the councils are present in the media, the more they are likely to affect the fiscal policy public debate and be perceived as independent. This paper focuses on fiscal councils' media influence as a potential instrument for increasing the transparency and accountability of public finances. Although the councils may well be uniquely positioned to promote fiscal transparency and accountability, how far do they really achieve this goal in practice? 


\section{DATA AND METHODOLOGY}

Data for this study were collected from a questionnaire designed by the author and filled out by representatives of fiscal councils in 18 EU countries. The full questionnaire is shown in the Appendix and the councils that responded are listed in Table A1. The overall response rate was 72\% (18 out of 25 fiscal councils). Responses from the fiscal councils in Croatia, Hungary, Ireland, the Netherlands, Sweden and the United Kingdom were selected for more in-depth study, and were supplemented with analysis of research papers and reports on their operation.

The questionnaire was designed and processed as anonymous in order to obtain a higher response rate and assure respondents of the confidentiality of their responses.

\section{TABLE 1}

Number and percent of answers to individual questions in the questionnaire $(N=18)$

\begin{tabular}{|c|c|c|}
\hline Questions (variable) & $\mathbf{N}$ & $\%$ \\
\hline How does your fiscal council communicate with the public? & 18 & 100 \\
\hline How often does your fiscal council communicate with the public? & 16 & 89 \\
\hline $\begin{array}{l}\text { What is the average annual media coverage of the activities of your fiscal } \\
\text { council? }\end{array}$ & 13 & 72 \\
\hline $\begin{array}{l}\text { Which of the media issues the largest number of releases on the work of } \\
\text { your fiscal council? }\end{array}$ & 16 & 89 \\
\hline How do you assess the media visibility of compliance with fiscal rules? & 17 & 94 \\
\hline How do you assess the media visibility of noncompliance with fiscal rules? & 16 & 89 \\
\hline $\begin{array}{l}\text { Please describe the reaction of the government in relation to the } \\
\text { assessment of noncompliance with national fiscal rules }\end{array}$ & 15 & 83 \\
\hline How to increase the media visibility of compliance with the rules? & 15 & 83 \\
\hline $\begin{array}{l}\text { Does the higher media visibility of compliance with the rules and more } \\
\text { effective communication of the council contribute to transparency and } \\
\text { (politicians') accountability in the budget process? }\end{array}$ & 15 & 83 \\
\hline $\begin{array}{l}\text { How to increase the impact of councils on fiscal transparency and } \\
\text { (politicians') accountability in the budget process? }\end{array}$ & 11 & 61 \\
\hline $\begin{array}{l}\text { How do you estimate the level of information of your citizens about the } \\
\text { existence and activities of your fiscal council? }\end{array}$ & 15 & 83 \\
\hline $\begin{array}{l}\text { What has so far been the impact of your fiscal council on public } \\
\text { information about the state of public finances and on the increase in fiscal } \\
\text { transparency and (politicians') accountability in the budget process? }\end{array}$ & 17 & 94 \\
\hline $\begin{array}{l}\text { How does the public respond to the information in the media about the } \\
\text { lack of transparency and about (politicians') responsibility in the budget } \\
\text { process? }\end{array}$ & 13 & 72 \\
\hline $\begin{array}{l}\text { How do fiscal rules and fiscal councils influence transparency and } \\
\text { (politicians') accountability in the budget process? }\end{array}$ & 14 & 78 \\
\hline $\begin{array}{l}\text { Do you think that fiscal rules and fiscal councils can be powerful } \\
\text { communication tools in order to increase fiscal transparency and } \\
\text { (politicians') accountability in the budget process? }\end{array}$ & 17 & 94 \\
\hline
\end{tabular}

Source: Questionnaire responses. 
Graph 1 shows a comparison of the distribution of ratings for the question of how fiscal councils influence transparency and the accountability of politicians for the management of public finances. The results show that four out of 14 councils evaluate "public information disclosure" as the best way to influence the transparency and accountability of politicians in managing public finances. This was followed by "communication through the media" and "promotion of transparency and accountability". Two councils each highlighted "public disclosure of analysis, evaluation and reports" and "promoting good practice through transparency in the work of fiscal council".

\section{Graph 1}

Frequency of different answers to the question "How do fiscal rules and fiscal councils affect transparency and accountability of politicians for the management of public finances?"

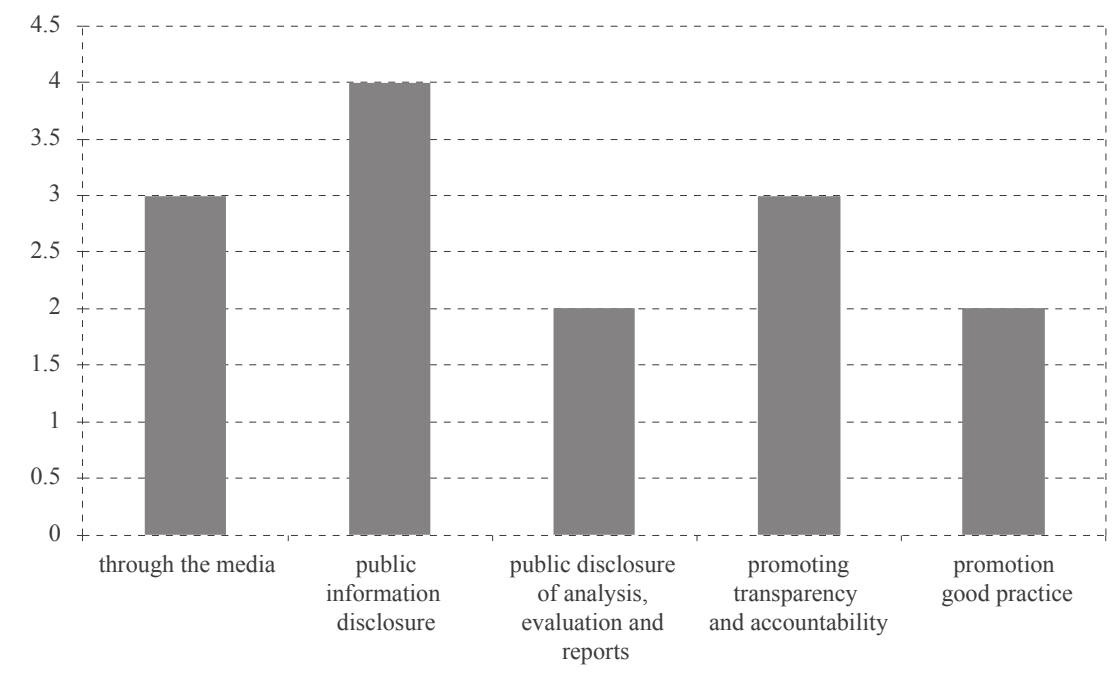

Source: Questionnaire responses.

Explanation of responses:

Through the media - general information on public finances provided to the public through the media;

Public information disclosure - by publicly disclosing information about compliance with fiscal rules and frequent communication with the media;

Public disclosure of analysis, evaluation and reports - systematic communication of analysis, evaluation and reports produced by fiscal councils;

Promoting transparency and accountability - general efforts to promote fiscal transparency and accountability;

Promoting good practice - setting an example through the transparency of the work of the fiscal council.

Graph 2 shows the frequency of answers to questions on the impact of fiscal councils, as assessed by respondents working for the councils. Not surprisingly, the 
majority of respondents, nine out of 15 , evaluated the impact of councils on the state of public finances and fiscal transparency as "good". Five respondents evaluated the impact of their councils as "sufficient", two as "very good", and one as "insufficient".

\section{GRAPH 2}

Frequency of different answers to the question "What is the impact of your fiscal council on public information on the state of public finances, and on fiscal transparency and accountability of politicians in the budget process?"

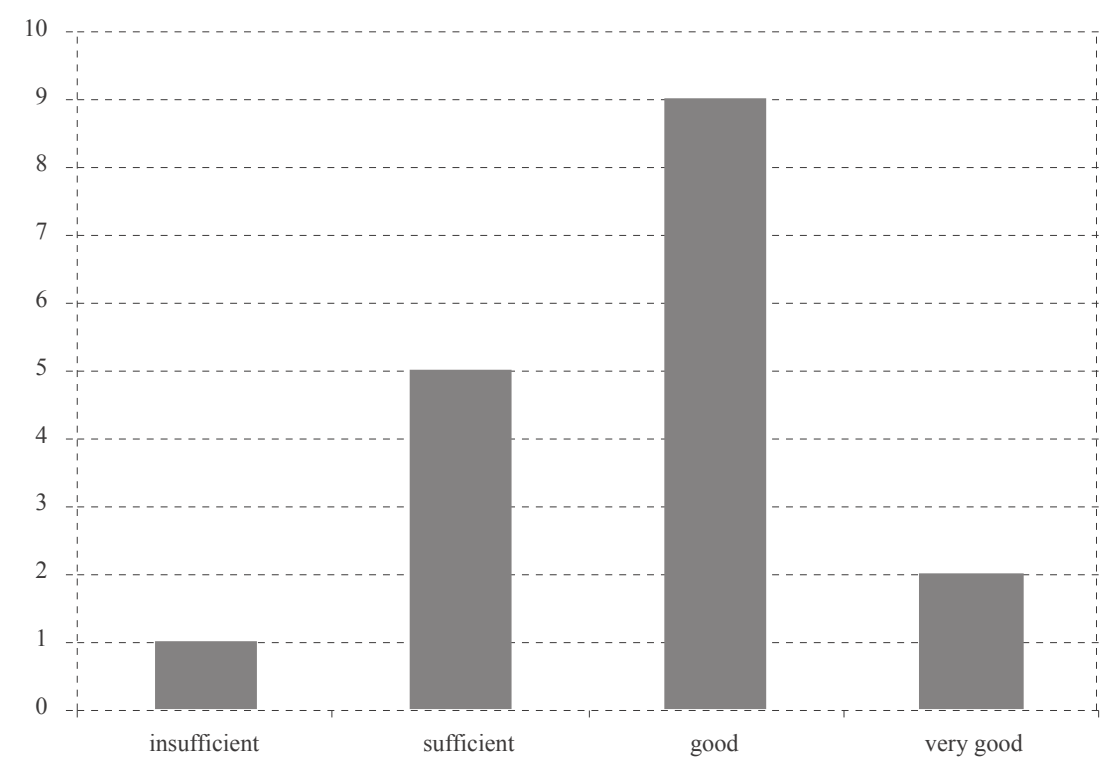

Source: Questionnaire responses.

Responses (not shown here) to related questions suggested a widespread lack of citizen awareness of the councils' existence and activities; the relatively high effectiveness of communication through the media; also, the more widespread use of disclosure of information on councils' websites rather than in the media.

Regarding channels of communication, all fiscal councils provided information on their websites (Table 2). Many also used press releases, interviews, press conferences, presence in social media groups, and briefings. Only one council (in Latvia) developed a communication strategy fully in line with OECD recommendations. ${ }^{3}$

\footnotetext{
${ }^{3}$ The OECD principles for Independent Fiscal Institutions (IFIs) state that "IFIs should develop effective communication channels from the outset, especially with the media, civil society, and other stakeholders". (see OECD, 2020).
} 
TABLE 2

Channels of communication with the public

\section{Commu-}

nication AT CY DK FR EL LV LT LU HR IE HU MT NL DE PT RO SE UK $\Sigma$ modes

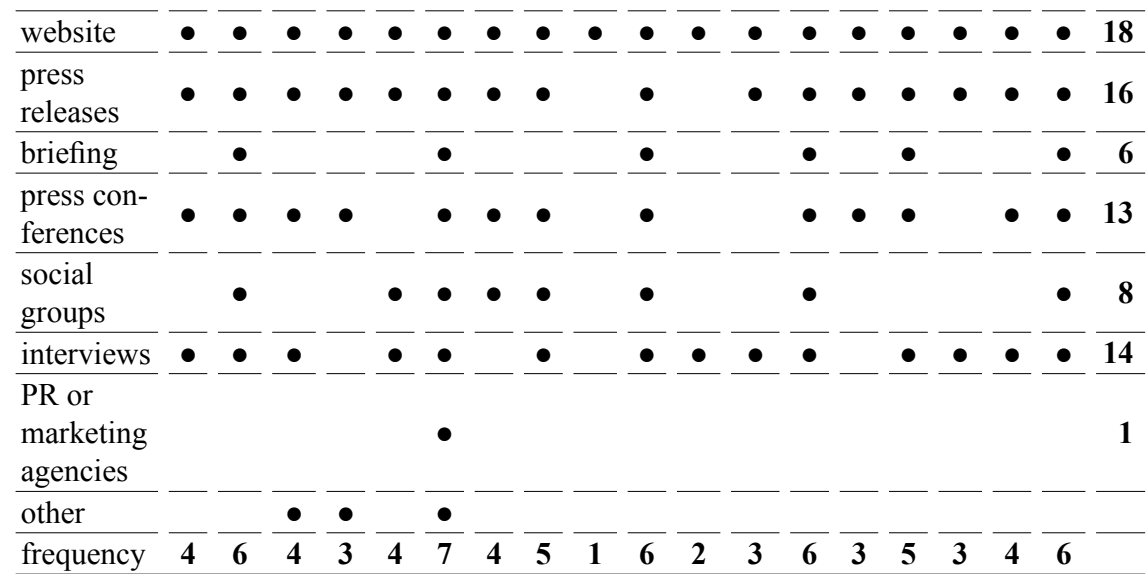

Source: Questionnaire responses.

Answers to Question 3 on the timing of councils' communications (Table A2) suggest that this is most intense for major fiscal events (for 12 out of 18 councils) and disclosure of information on compliance/non-compliance with fiscal rules (10 councils). The councils most often give warnings about the state of public finances (Table A3) in the event of there being a discrepancy between the proposed budget and the outlined objectives, as well as in case of overoptimistic forecasts ( 9 councils each).

Media reports on fiscal councils' communications (Table A4) mostly address analyses, assessments and reports of the councils (as reported by 15 councils); councils' criticism of government fiscal policy ( 9 cases); their reports on trends in deficits and public debts ( 8 cases); and their assessments of fiscal transparency and accountability in the budget process ( 5 cases). One can detect a difference in councils' assessment as between what they communicate and what the media report (Table 3). The media mostly cover analyses, evaluation and reports; criticisms of government fiscal policy and changes in deficits and public debt; and issues in transparency and accountability in the budget process or in councils' activity. 
TABLE 3

Media coverage of most common topics communicated by councils

\begin{tabular}{|c|c|c|}
\hline Communications & Alerts & Media releases \\
\hline $\begin{array}{l}\text { Most important fiscal } \\
\text { events }\end{array}$ & $\begin{array}{l}\text { Discrepancy between } \\
\text { proposed budgets and fiscal } \\
\text { goals / over-optimistic } \\
\text { forecasts }\end{array}$ & $\begin{array}{l}\text { Analyses, evaluations and } \\
\text { reports }\end{array}$ \\
\hline $\begin{array}{l}\text { Information on compliance } \\
\text { / non-compliance with } \\
\text { fiscal rules }\end{array}$ & $\begin{array}{l}\text { Excessive spending / raising } \\
\text { public awareness of sound } \\
\text { public finances }\end{array}$ & $\begin{array}{l}\text { Criticisms of government } \\
\text { fiscal policy and of changes } \\
\text { in fiscal deficits and public } \\
\text { debt }\end{array}$ \\
\hline $\begin{array}{l}\text { Announcement of fiscal } \\
\text { policy changes / fiscal } \\
\text { policy failures }\end{array}$ & Actual state of fiscal policy & $\begin{array}{l}\text { Releases on transparency } \\
\text { and accountability in the } \\
\text { budget process / councils' } \\
\text { activities }\end{array}$ \\
\hline
\end{tabular}

Source: Questionnaire results and author's comparison.

Somewhat surprising were answers to Question 5, on the media that issue the largest number of releases on the work of councils. Print media were highlighted by 16 out of 17 councils, while only five noted the digital media. Given the growing influence and importance of digital media, fiscal councils were expected to redirect communication to these media in the future.

Only four councils use international media to send messages about the government's fiscal policy to the world public (Question 7). This is surprising given that international news agencies tend to affect financial markets and "penalize the countries that violate fiscal rules" (Eyraud and Wu, 2015). Seven councils do not use international media, and seven consider it sufficient that the foreign media themselves transmit information published on councils' websites, at press conferences, through social media or foreign correspondents. For example, the Irish IFAC sends reports for publication to the Network of European Council (EUFI) website.

Information on compliance with fiscal rules is publicly available on all councils' web pages (Table 4). Most councils present reports on compliance with fiscal rules through press releases and presentations in parliament (12 each), half present reports at press conferences, and fewer than half at briefings with journalists. 
AT CY DK FR EL LV LT LU HR IE HU MT NL DE PT RO SE UK

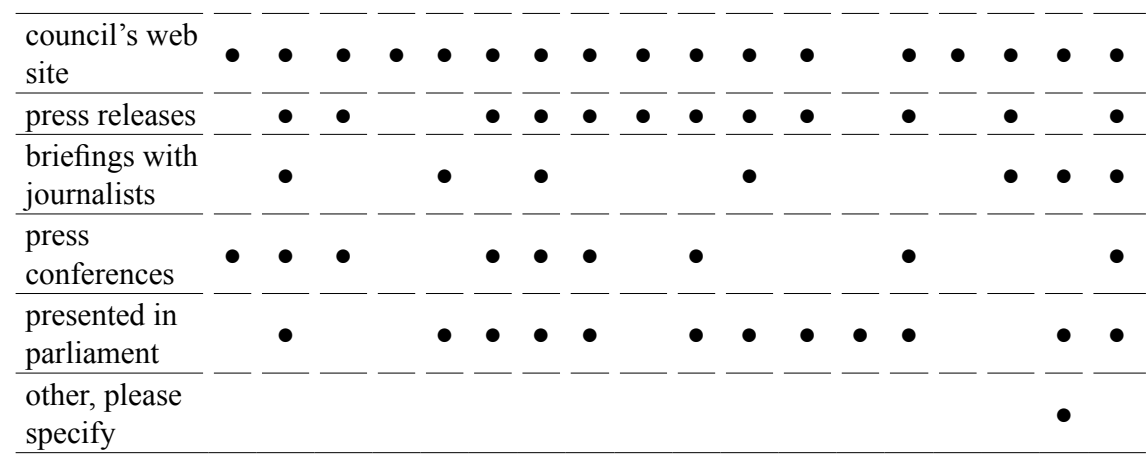

Source: Author's questionnaire results.

Other:

Germany - by presentation in the parliament and legally secured in special cases (presentation of reports in case of non-compliance with fiscal rules in the Federal Parliament and in the State Parliaments).

Netherlands - The Quarterly Review, a CPB publication related to the budget cycle, provides numerous opportunities for assessing compliance with national and EU fiscal rules.

Portugal - a web site release - in the annual fiscal performance reports, annual budget plans and medium-term stability programs.

Sweden - annual report is published in electronic and printed form.

Fewer than half of the councils surveyed rate the visibility of published information they provide as adequate, i.e. transmitted or published by all major media, followed by a public debate. In Sweden, for example, the annual report draws a lot of attention from newspapers and television. Newspaper articles and editorials comment on the report, and representatives refer to it in parliamentary debates. Eight councils also replied that all the mainstream media transmitted or published information on compliance with the rules, but this was not followed by public discussion. The Dutch council judges that the occasional visibility of CPB data allows assessment of compliance with the rules, but most of the time more attention is paid to deficit forecasts, as assessments of compliance with the rules are carried out by another agency, the National Council. ${ }^{4}$

Regarding the media visibility of councils' assessments of fiscal rules (Question 11) just over half (9 out of 17) of the councils replied that information on noncompliance was transmitted by all major media and followed by public debate. In almost a third of the cases, mainstream media did transmit the information, but there was no public debate. For instance, councils in France and Romania reported

\footnotetext{
${ }^{4}$ More: www.raadvanstate.nl/the-council-of-state. At the time of the survey the CPB was listed in the EU Independent fiscal institutions database. Today, both CPB and National Councils (which is active since 2014) are members of the network of the EU Independent Fiscal Institutions (EUIFIS).
} 
that information on non-compliance was published in the media very seldom or never. Unsurprisingly, media reported more often on non-compliance than on compliance with the rules. This probably reflects the well-known media market strategy to provide readers with the negative news and criticism of government policies that they find more attractive. Furthermore, more than half of the councils (9 out of 17) stated that the government felt obliged to explain the reasons for the non-compliance identified by fiscal councils; more a than third ( 7 out of 17) replied that the government did not respond publicly (Question 12).

Governments mostly responded to critical views of fiscal policy by respecting criticism and becoming more transparent (6 out of 17 councils), and by explaining the state of fiscal policy (Question 15). Almost half of the councils (6 out of 13) indicated that citizens did not react publicly even though they were mostly aware of the lack of transparency and accountability in the budget process (Question 21). Very few councils responded that the public was responsive to discussions and pressed for transparency and accountability. Very few also responded that they felt the public lacked knowledge and interest in public finances ( 2 out of 13 councils). This indicates that the councils do have an influence on the government through the media, and that the public does have an influence on the government, but not to the extent expected in the policy literature. The public generally hardly reacts to information about the lack of fiscal transparency and accountability.

How could fiscal councils increase their impact on transparency and accountability in the future? Answers summarised in Table 5 suggest a few good practices: increasing the number of public debates on fiscal policy in the media (9 out of 18 councils); strengthening their powers through adjustments in national legislation (7 out of 18); and communicating more efficiently with the public (6 out of 18). The questionnaire further indicated that for the vast majority of councils, communication with the public and public information were not regulated by law (see Table A5). The majority of councils did not view staffing problems as a major obstacle to increasing its influence (Table A6).

A good starting point was that councils reported motivation of employees: 17 out of 18 councils saw good prospects for increasing their influence in the future. 


\section{TABLE 5}

How can the impact of councils on fiscal transparency and accountability in the budget process be increased?

AT CY DK FR EL LV LT LU HR IE HU MT NL DE PT RO SE UK

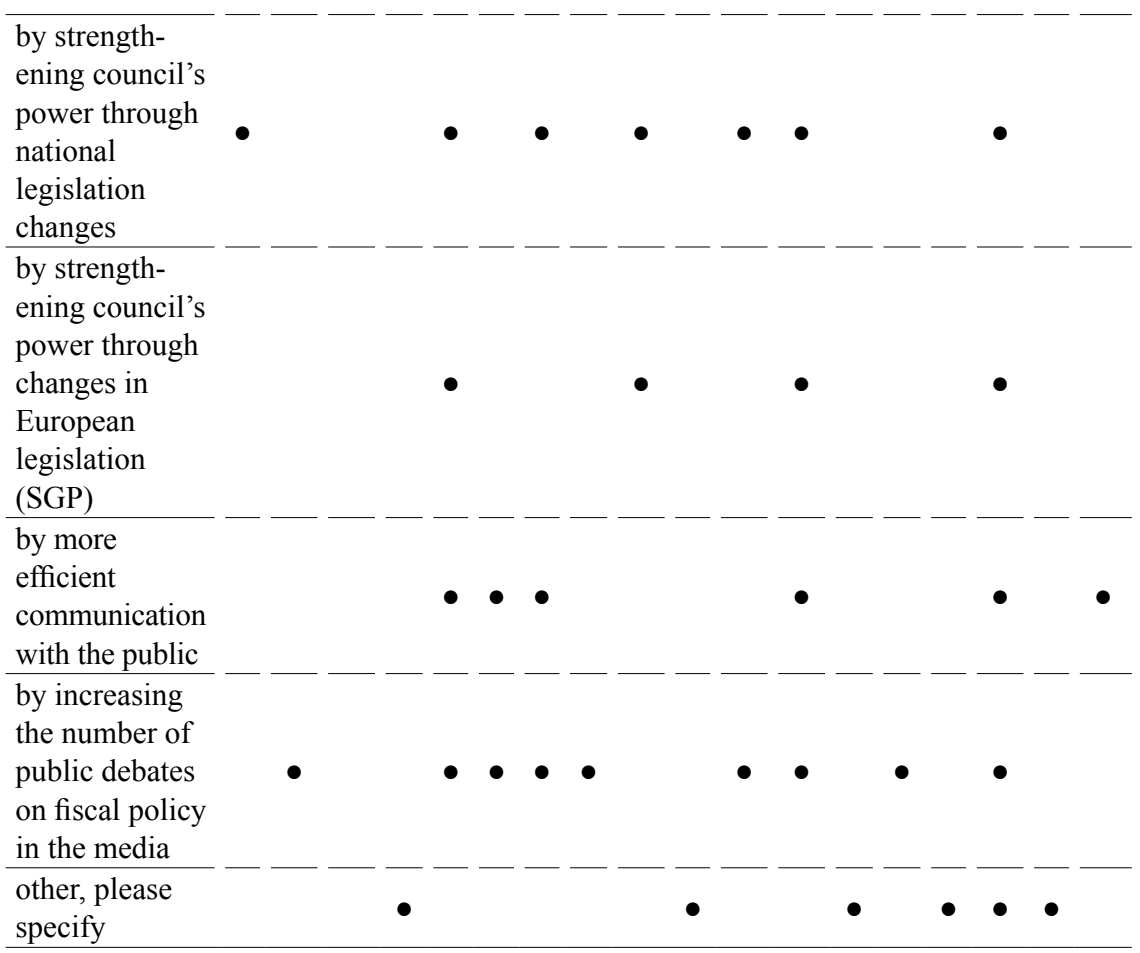

Source: Author's questionnaire results.

Other:

France - the influence is already high.

Ireland - by producing quality analyses and effectively communicating the results with the parliament.

Portugal - building a reputation is essential in order to ensure social significance. If quality or independence is lacking in its analysis, no marketing plan could preserve the fiscal council.

Romania - by increasing the public awareness to be implicated in the process of how the government spend the public money, not just in the short-term but also in the medium-term.

Sweden - A strong council needs a legislative background, but the legislative background does not guarantee a strong council. The strength of the institution ultimately depends on the quality and credibility of its work, not its legal status.

A closer look at fiscal councils in Croatia, Hungary, Ireland, the Netherlands, Sweden and UK provides additional insights. These councils seem to be aware of the importance of communication with the media for their role of "fiscal guardians".

In Ireland, the Netherlands Sweden and the UK communication with the public takes place in many different ways. By contrast, in Hungary it takes place only through a website and media interviews, and in Croatia only through a website. 
The Dutch council plans to improve its communication strategy by increasing activities in social media. Most council publications are reviewed in the print and electronic media.

These six councils mostly publish information on compliance with the rules on their websites through press releases, and by making presentations in parliament. Most active in terms of communication are the councils in Sweden and the UK. Respondents from the councils noted that information on compliance was transmitted by all important media, and was followed by public discussions, notably in Ireland, Sweden and the UK. In Croatia and Hungary, there was less public discussion of councils' findings.

Governments in these countries generally responded to the councils' findings on non-compliance with fiscal rules. In Sweden, the government was required to respond before passing another budget. In the UK, the government had to announce whether it had taken corrective measures. The Swedish council assessed fiscal transparency both as part of its regular duties and in its annual report. Governments in these countries appreciated councils' work. In Sweden, the government regularly explained the reasons for the situation in response to the council's criticism. In the UK, the council presented information for others to judge and did not openly express critical views.

Most of these six councils believed that preparing public reports that influence media reporting had the greatest impact on fiscal transparency (Table A7). All six councils assessed their impact on public information and on increasing fiscal transparency and accountability as good. Councils in the Netherlands and the UK pointed out that they generally worked with a high level of transparency. Public reactions to information that councils provide to the media vary across countries. In Croatia, these responses show up in a large number of follow-up reactions in the media; in Hungary, in public hearings and media pressure; in Ireland, in critical press reports; and in Sweden, in strong public support for fiscal discipline and the potentially high cost of financial irresponsibility.

\section{CONCLUSION}

This paper presents the findings from a questionnaire on media communication practices of fiscal councils in EU countries as a potential tool for increasing the transparency and accountability of public finances. Their mandate is to increase the visibility of compliance with fiscal rules through active communication with the public. More effective communication should in theory help improve fiscal transparency by making politicians accountable to the public for their management of public finances. The purpose of the questionnaire was to assess to what extent this has been the case in practice. The findings show the following:

The best practices for fiscal councils to influence accountability of politicians in managing public finances seem to be public disclosure of information about 
compliance with fiscal rules, frequent communication with the media, promotion of transparency and accountability, publication of analyses, evaluations and reports, and, last but not least, open and transparent work by fiscal councils themselves.

Most fiscal councils assess the influence of their own work on the state of public finances and fiscal transparency as good. They find that they exert influence on the government and the public through the media, but not to the extent they would like. This is reflected, for instance, in the weak public reaction to councils' findings on the lack of fiscal transparency, and suggests that the councils need to put more effort into their media communication strategies. One obvious choice would be to make more intensive use of the digital media, as their influence is growing relative to traditional outlets like print.

Their influence could also be enhanced by increasing the number of public debates on fiscal policy in the media. Some councils would also benefit from stronger anchoring of their powers in national legislation, as recommended by the OECD.

In sum, this paper provides some tentative evidence that fiscal councils in EU countries are able to help promote fiscal transparency and accountability. The councils themselves see some benefits of their work, and their monitoring of adherence to fiscal rules and warnings about excessive government spending noticed in the media. This informs the public, and may in turn influence politicians' ratings, thereby helping contribute to greater accountability in the management of public finances.

\section{Disclosure statement}

No potential conflict of interest was reported by the author. 


\section{REFERENCES}

1. Calmfors, L. and Wren-Lewis, S., 2010. What should fiscal councils do? Stockholm: Stockholm Universit; Swedish Fiscal Policy Council; Oxford University.

2. Debrun, X. [et al.], 2013. Functions and impact of the fiscal councils. Washington: IMF.

3. Eyraud, L. and Wu, T., 2015. Playing by the Rules: Reforming Fiscal Governance in Europe. IMF Working Paper, No. 15/67. https://doi.org/10.5089/ 9781484300282.001

4. IMF, 2013. The Functions and Impact of Fiscal Councils. Washington: International Monetary Fund.

5. IMF, 2014. Fiscal Transparency Code. Washington: International Monetary Fund.

6. IMF, 2016. How Does the IMF Encourage Greater Fiscal Transparency? Washington: International Monetary Fund.

7. IMF, 2019. Fiscal Transparency Code. Washington: International Monetary Fund.

8. Kopits, G. and Craig, J., 1998.Transparency in Government Operations. IMF Occasional Paper, No. 158.

9. OECD, 2002. Best Practice for Budget Transparency. Paris: OECD. https:// doi.org/10.1787/budget-v1-art14-en

10. OECD, 2013. Government at a Glance 2013. Paris: OECD. http://dx.doi.org/ 10.1787/gov_glance-2013-en

11. Schick, A., 2010. Post-Crisis Fiscal Rules: Stabilising Public Finance while Responding to Economic Aftershocks. OECD Journal on Budgeting, 2, pp. 1-18. https://doi.org/10.1787/budget-10-5km7rqpkqts 1

12. Schick, A., 2013. Lessons from the crisis. OECD Journal on Budgeting, 12(3), pp. 1-29. http://dx.doi.org/10.1787/budget-12-5k47tb29wn6h

13. Schuknecht, L., 2004. EU fiscal rules Issues and Lessons from political economy. ECB Working paper series, No 421.

14. Wyplosz, C., 2012. Fiscal Rules: Theoretical Issues and historical Experiences. National Bureau of Economic Research. Working Paper, No.17884. https://doi.org/10.3386/w17884

15. Wyplosz, C., 2015. The Eurozone crisis: Too few lessons learned. The Eurozone Crisis: A Consensus of the Causes and a Few Possible Remedies. London: CEPR Press. 


\section{QUESTIONNAIRE}

1. How does your fiscal council communicate with the public?

(multiple replies possible)

- web page

- press releases

- briefings

- press conferences

- social groups (YouTube, Twitter, Facebook, etc.)

- interviews

- PR or marketing agency

- other, please specify

2. How often does your fiscal council communicate with the public?

- a week

- a month

- quarterly

- semi-annually

- a year

- once a year

- other, please specify

3. When does your fiscal council usually communicate with the public? (multiple replies possible)

- when there are significant fiscal events (planning the state budget, presenting the draft state budget, the debate on the state budget in Parliament, the execution of the state budget)

- when changes in fiscal policy are being announced

- when tax-policy is out of the set framework

- in the time of the release of the compliance/incompliance with fiscal rules

- ahead of parliamentary elections and during the election campaign in order for the voters to be fairly informed about fiscal policy

- in case of major failures in the conduction of fiscal policy

- other, please specify

4. What is the average annual media coverage of the activities of your fiscal council?

- more than 10 releases in the media

- more than 20 releases in the media

- more than 50 releases in the media

- more than 100 releases in the media

- more than 150 releases in the media

- other, please specify 
5. Which media issue the largest number of releases on the work of your fiscal council?

- print media (dailies, weeklies, monthlies, etc.)

- electronic media (radio, television, etc.)

- digital media (social groups, Facebook, Twitter, YouTube, etc.)

- online media (news portals, etc.)

\section{Additional information}

6. Which area do most of the media reports address?

(multiple replies possible)

- activities of the Council

- analysis, assessments and reports of the Council

- criticism of the government's fiscal policy

- trends in deficit and public debt

- transparency and accountability in the budget process

- other, please specify

7. What international media does your fiscal council use to send a message about the government's fiscal policy to the world public?

(multiple replies possible)

- news agencies (Reuters, Bloomberg, etc.)

- The Financial Times and the like

- The Economist and the like

- international television channels (CNN, CNBC, etc.)

- they do not use any international media

- other, please specify

8. How much funding was allocated from the budget of your fiscal council for marketing and public relations in 2015 and 2016? (amount in EUR)

- in 2015

- in 2016

- no data on the funding

9. Is the monitoring of the compliance with fiscal rules publicly available? (multiple replies possible)

- on the web site of the Council

- press releases

- briefing with journalist

- press conferences

- presented in the Parliament

- other, please specify

10. How do you assess the media visibility of the compliance with fiscal rules?

- information about this is published/broadcast in all major media, followed by a public debate

- information about this is published/broadcast in all major media, no public debate 
- information about this is published/broadcast only in some media

- there is no, or insufficient, information about this in the media

- other, please specify

11. How do you assess the media visibility of noncompliance with fiscal rules?

- information about this is published/broadcast in all major media, followed by a public debate

- information about this is published/broadcast in all major media, no public debate

- information about this is published/broadcast only in some media

- there is not, or insufficient, information about this in the media

- other, please specify

12. Please describe the reaction of the government in relation to the assessment of noncompliance with national fiscal rules

- reacts extremely negatively to the fiscal institution

- explains why it does not comply

- publicly announces it is taking corrective steps

- publicly explains why it does not take corrective steps

- usually does not react publicly

- other, please specify

13. How can IFIs contribute to the increase in the (politicians') accountability for not complying with fiscal rules?

(multiple replies possible)

- by better informing the public through the media about the importance of the compliance with the rules and the consequences of the noncompliance

- by educating politicians

- by educating the public

- by the influence of IFIs through the media on the politicians' reputations

- other, please specify

14. How to increase the media visibility of compliance with the rules?

- by more efficient communication with the public

- by creating a communication strategy with the public

- by earmarking the funds for marketing

- by increasing the funds for marketing

- by selecting individuals that have communication skills to head the institution

- other, please specify

15. Please describe the reaction of the government to critical views by your fiscal council on fiscal policy published in the media?

- The government generally respects the criticism, becoming more transparent and accountable.

- The government generally respects the criticism, but does not become more transparent and accountable.

- The government explains the reasons for the state of fiscal policy.

- The government rarely appreciates criticism. 
- The government threatens that budgetary resources for the work of fiscal institutions will be reduced.

- The government reacts extremely negatively.

- The government generally does not react.

- Other, please specify.

16. How does your fiscal council affect the fiscal transparency and (politicians') accountability in the budget process?

(multiple replies possible)

- by promoting fiscal transparency and accountability

- by analysing fiscal transparency

- by supervising fiscal sustainability

- by preparing public reports that have significant media impact

- by promoting sound fiscal policy

- other, please specify

17. What do you see as the main cause of the growth of the deficits and public debts in your countries in the period from 2008 to 2015?

(multiple replies possible)

- excessive government spending in (good) times before the crisis

- poor risk management before the crisis

- inadequate and belated government response to the global financial crisis

- fiscal irresponsibility and lack of transparency

- politicians were disoriented during the crisis

- absence of fiscal rules

- noncompliance with fiscal rules

- non-existence of independent fiscal institutions

- introduction of flexible rules

- susceptibility to political discretion

- political misuse of state finances

- bad and irresponsible policies of EU member states

- increased spending before the elections and transfer of costs to the future generations

- insufficient and biased information to the public about the state of public finances

- there is no problem with deficit and public debt, and the public finances were stable

- other, please specify

18. Does the higher media visibility of the compliance with rules and more effective communication of IFIs contribute to transparency and (politicians') accountability in the budget process?

- yes, please specify how

- no, please specify reasons 
19. How to increase the impact of IFIs on fiscal transparency and (politicians') accountability in the budget process?

- by strengthening the power of IFIs through changing national legislation

- by strengthening the power of IFIs through changing European legislation (Stability and Growth Pact)

- by more efficient communication with the public

- by increasing the number of public debates on fiscal policy in the media

- other, please specify

20. What are the obstacles to any increase in the impact of your fiscal council on fiscal transparency and (politicians') accountability in the budget process? (multiple replies possible)

- insufficient staffing of Council

- lack of a communication strategy with the public

- council is not independent in the performance of its work

- government ignores Council media views on the state of fiscal policy

- media views and public discussions do not contribute to the better state of public finances

- low level of democracy in a society, which is why the impact of public has weakened

- low level of press freedom, which is why the media do not publish critical views on the government's fiscal policy

- other, please specify

21. How does the public respond to the information in the media about the lack of transparency and (politicians') responsibility in the budget process?

- by public debates and pressing politicians on more transparent and more responsible behaviour in the budget process

- by public discussions, but without pressing politicians on more transparent and more responsible behaviour in the budget process

- by constantly pressing politicians on more transparent and more responsible behaviour in the budget process

- has evidence of the lack of transparency and (politicians') responsibility in the budget process, but is not responding

- has no knowledge of and shows no interest in the state of public finances

\section{Additional information}

22. How do you estimate the level of information of your citizens about the existence and activities of your fiscal council?

- insufficient

- barely sufficient

- good

- very good

- exceptionally well-informed 
23. What has so far been the impact of your fiscal council on the public information about the state of public finances and on the increase in fiscal transparency and (politicians') accountability in the budget process?

- insufficient

- sufficient

- good

- very good

- excellent

\section{Additional information}

24. How do fiscal rules and IFIs influence transparency and (politicians') accountability in the budget process?

- by informing the public through media, and the public then influences the politicians' reputation and rating at the elections

- by public disclosure of information about the compliance with fiscal rules and increased communication with the media

- by enhanced communication analysis, evaluation and reporting of independent fiscal institutions

- by promoting fiscal transparency and accountability

- by transparency of the work of an independent fiscal institution as an example of good practice

- other, please specify

25. When does your fiscal council especially issue warnings about the state of public finances? (multiple replies possible)

- in the event of a conflict between the proposed budget and the goals set out

- in the case of overoptimistic forecasts

- in the event of excessive government spending

- in the case of unsustainable tax policy

- in the case of worse fiscal performance than anticipated

- to indicate the actual state of fiscal policy

- to raise public awareness on the importance of sound public finances

- other, please specify

26. Do you think that fiscal rules and IFIs can be powerful communication tools in order to increase fiscal transparency and (politicians') accountability in the budget process?

- yes, please specify how

- no, please specify reasons 
Table A1

EU fiscal councils that responded to the questionnaire

Country

Council

Year of

founding

\begin{tabular}{|c|c|c|}
\hline AT & Fiscal Advisory Council & 2002 \\
\hline $\mathrm{CY}$ & Fiscal Council & 2013 \\
\hline DK & Danish Economic Council & 1962 \\
\hline FR & High Council for Public Finance (HCFB) & 2013 \\
\hline EL & Parliamentary Budget Office & 2010 \\
\hline HR & Commission on Fiscal Policy & 2013 \\
\hline IE & Irish Fiscal Advisory Council (IFAC) & 2011 \\
\hline LT & State Audit Office & 2013 \\
\hline LV & Fiscal Discipline Council & 1990 \\
\hline LU & Court of Auditors & 1999 \\
\hline $\mathrm{HU}$ & Fiscal Council & 2009 \\
\hline MT & National Audit Office & 2013 \\
\hline NL & Netherlands Bureau for Economic Policy Analysis (CPB) & 1945 \\
\hline $\mathrm{DE}$ & Independent Advisory Board to the Stability Council & 2013 \\
\hline $\mathrm{PT}$ & Public Finance Council & 2012 \\
\hline RO & Fiscal Policy Council & 2010 \\
\hline SE & Swedish Fiscal Policy Council & 2007 \\
\hline UK & Office for Budget Responsibility (OBR) & 2010 \\
\hline
\end{tabular}

Source: Author. 
When does your fiscal council usually communicate with the public?

AT CY DK FR EL LV LT LU HR IE HU MT NL DE PT RO SE UK

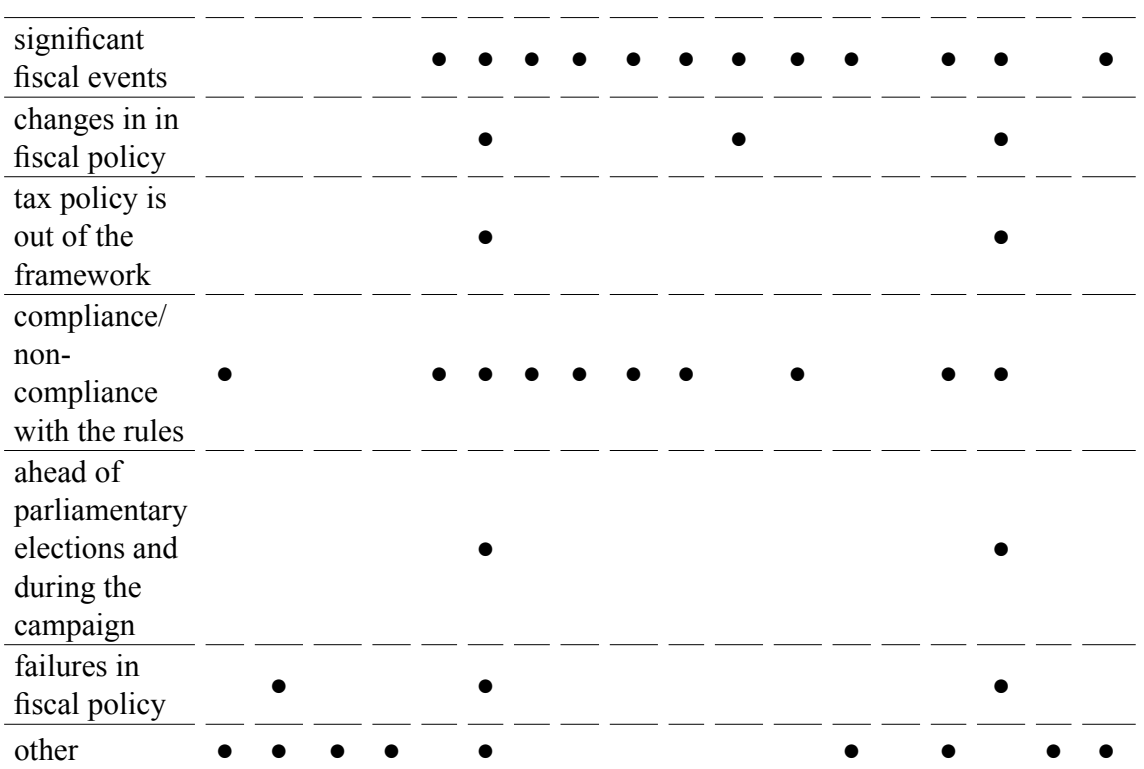

Source: Author's questionnaire results.

Other:

Austria - by publication calendar (studies, recommendations, etc.).

Cyprus - every fall and spring (specified in legislation) if it considers that EU or national rules have been breached.

Denmark - the Council meets twice a year and the Presidency prepare a report for each Council meeting. The report contains economic analysis and policy recommendations on economic policy, as well as short and medium-term forecasts on the key indicators of the Danish economy. The report also includes the Presidency assessment of fiscal policy goals - e.g. adherence to the national Budget Law, adherence to EU rules and assessment of long-term fiscal sustainability. The Presidency is independently responsible for the reports and acts as a Danish "fiscal watchdog". The preliminary version of the report is presented and discussed at the Council meeting. The reports are published immediately after the meeting. Council members' comments are added in the final version of the report. Following the Council meeting the Presidency holds a press conference.

France-for each budget and SGP.

Ireland - with regard to the first reply, the primary Council communicates with the public at the time of the release of the main reports. Council members and the president sometimes participate in media interviews throughout the year. The president usually participates in fewer media inclusions, the morning after the annual budget is announced in October each year, to give an initial reaction to the budget.

Latvia - the Law on Fiscal Discipline gives the Latvian Fiscal Council a broad mandate (Article 28) so that it communicates in all cases where it considers it important.

Netherlands - CPB publishes Quarterly Reviews, a budget cycle publication. This provides numerous opportunities for assessing compliance with national and EU fiscal rules. In September, opposition parties seek an analysis of their alternative budget. The CPB provides analysis of political parties'electoral programs. It also provides analysis of Government agreements and major additional policy packages. 
Portugal - usually when a publication is issued or when a senior council member intervenes at a public event. It publishes an average of 1.5 publications per month, but amount is not the same every month.

Romania - on the eve of parliamentary elections and during the election campaign to keep voters impartially informed - only when the Council is asked.

Sweden - FPC may decide to hold a press conference at a time when it believes there is a failure in fiscal policy (breach of fiscal rule) and a need for action (e.g. regarding fiscal effects of immigration in 2015). FPC does not hold regular press conferences and tries to stay away from direct involvement in the budget process or election campaigns.

$\boldsymbol{U K}$ - in the case of significant fiscal developments and medium-term forecasts while all other outputs are published at a time of the institution's own choosing. 
TABLE A3

When does your fiscal council especially give warnings about the state of public finances?

AT CY DK FR EL LV LT LU HR IE HU MT NL DE PT RO SE UK

conflict

between

proposed

budget and

goals set out
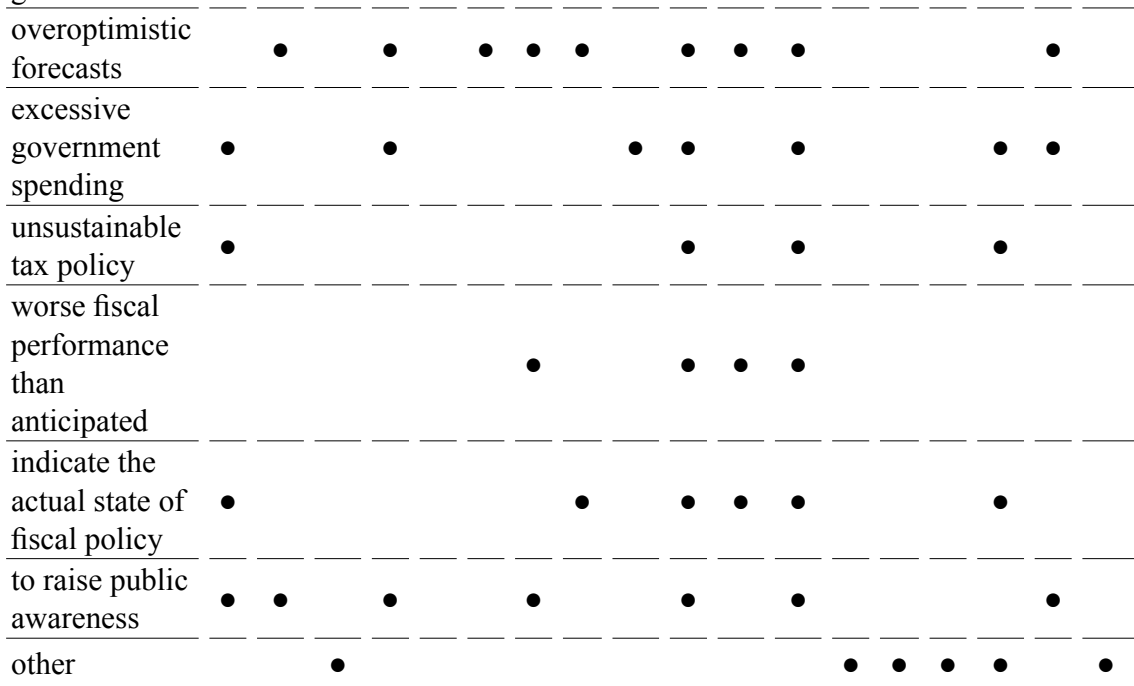

Source: Author's questionnaire results.

Other:

Denmark - the Council meets twice a year and the Presidency prepares a report for each of the meetings. The report contains economic analysis and policy recommendations on economic policy, as well as short-and medium-term forecasts on the key indicators of the Danish economy. It also includes the Presidency assessment of fiscal policy goals - e.g. adherence to the national Budget Law and to EU rules, and assessment of long-term fiscal sustainability. The Presidency is independently responsible for the reports and acts as a Danish "fiscal watchdog". The preliminary version of the report is presented and discussed at the Council meeting. The reports are published immediately after the meeting. Council members' comments are added in the final version of the report. Following the Council meeting, the Presidency holds a press conference.

Germany - alerts are inseparable with the tasks of the Stability Council. It makes significant reference to budgetary surveillance to avoid budgetary urgency (warning of a specified budgetary emergency) and to monitoring compliance with EU budgetary discipline requirements (more on tasks on the Council's website).

Netherlands - the CPB provides the data for assessment. It does not provide explicit warnings.

Portugal - whenever CFB publishes its regular reports. Council does not publish analyses or comments in reaction to particularly events.

Romania - in the case of major fiscal measures envisaged by the government.

$\boldsymbol{U K}-O B R$ publishes its forecasts at the same time as the Ministry of Finance the main announcement of the policy. The OBR does not give warnings about the "state" of public finances, but presents detailed analyses so that everyone can judge the fiscal position. 
TABLE A4

Which topics do media reports address?

AT CY DK FR EL LV LT LU HR IE HU MT NL DE PT RO SE UK

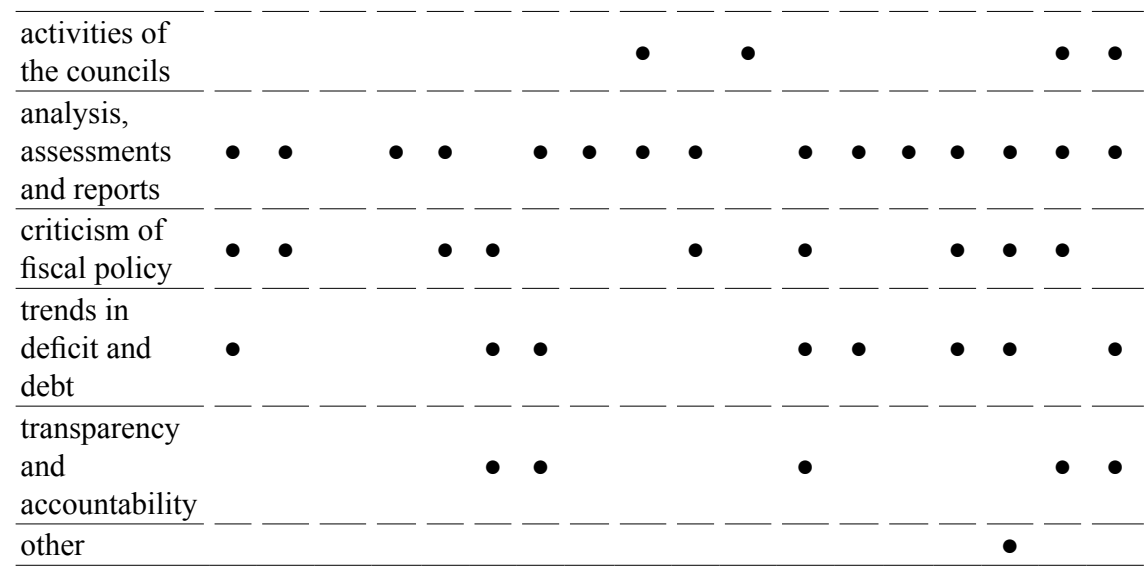

Source: Author's questionnaire results. 
Table A5

The legal determination of the councils' communication with the public

\begin{tabular}{ll} 
Council & Fiscal Responsibility Act (FRA) - Communication with the public \\
\hline Denmark & $\begin{array}{l}\text { The type and timing of the reports is published on } \\
\text { De Økonomiske Råd }\end{array}$ \\
\hline Under the law in place, the council publishes opinions on \\
Haut Conseil des Finances Publiques \\
There is no FRA or legally determined public release \\
of information, but it does publish certain information on \\
Parliamentary Budget Office
\end{tabular}

Source: Author. 


\section{TABLE A6}

What are the obstacles to increasing the impact of your council on fiscal transparency and accountability in the budget process?

AT CY DK FR EL LV LT LU HR IE HU MT NL DE PT RO SE UK

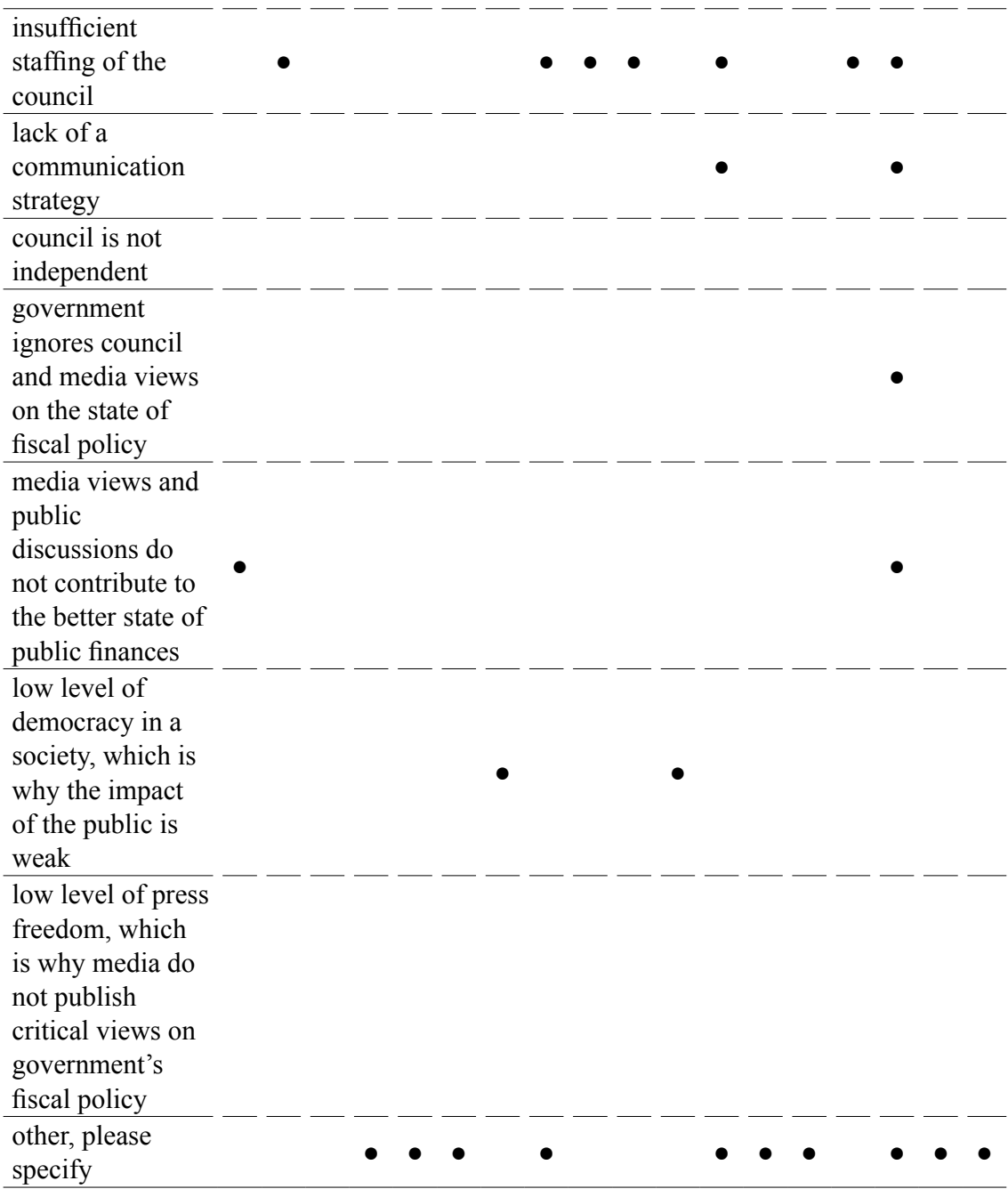

Source: Author's questionnaire results.

\section{Other:}

France - no obstacles.

Germany - no obstacles, as the federal budgetary autonomy system does not permit direct control of the budget process, e.g. the process of drafting government budgetary and financial plans by the central instance. The parliaments enacting the budgetary and financial plans are highest instance representing the public.

Greece - our office should have a more "executive role" (in the legislative sense).

Ireland - insufficient staff of the council is currently not the major issue but could be a limiting factor in the future if demands on the council increase.

Latvia - no obstacles. It is necessary to implement a developed communication strategy. 
Luxembourg - still lacking access to data; "comply or explain" principle could be clarified in the long term through the Memorandum of understanding.

Malta - usually media do not properly emphasize the state of public finances, unless there are significant risks of severe deterioration in fiscal position, or serious noncompliance with the EU fiscal rules.

Netherlands - no major obstacles.

Romania - reputational costs for politicians and government are not contained in legislation.

Sweden - we are a small institution (staff of five people) so there are limits to what we can do, but we really enjoy independence and are free to communicate with the public whenever and in whatever way we choose.

$\boldsymbol{U K}$ - no obstacles. 


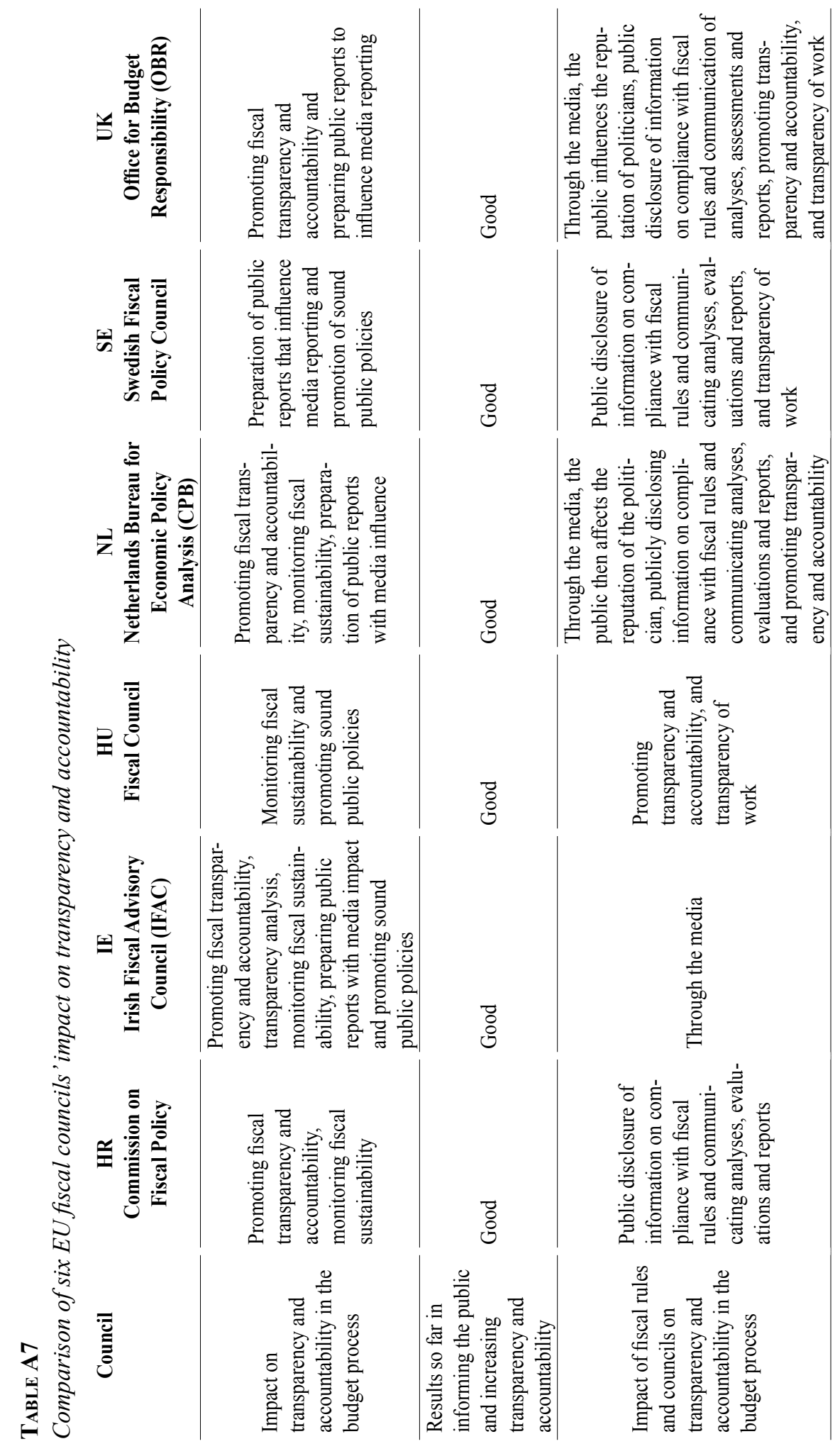

383 
384
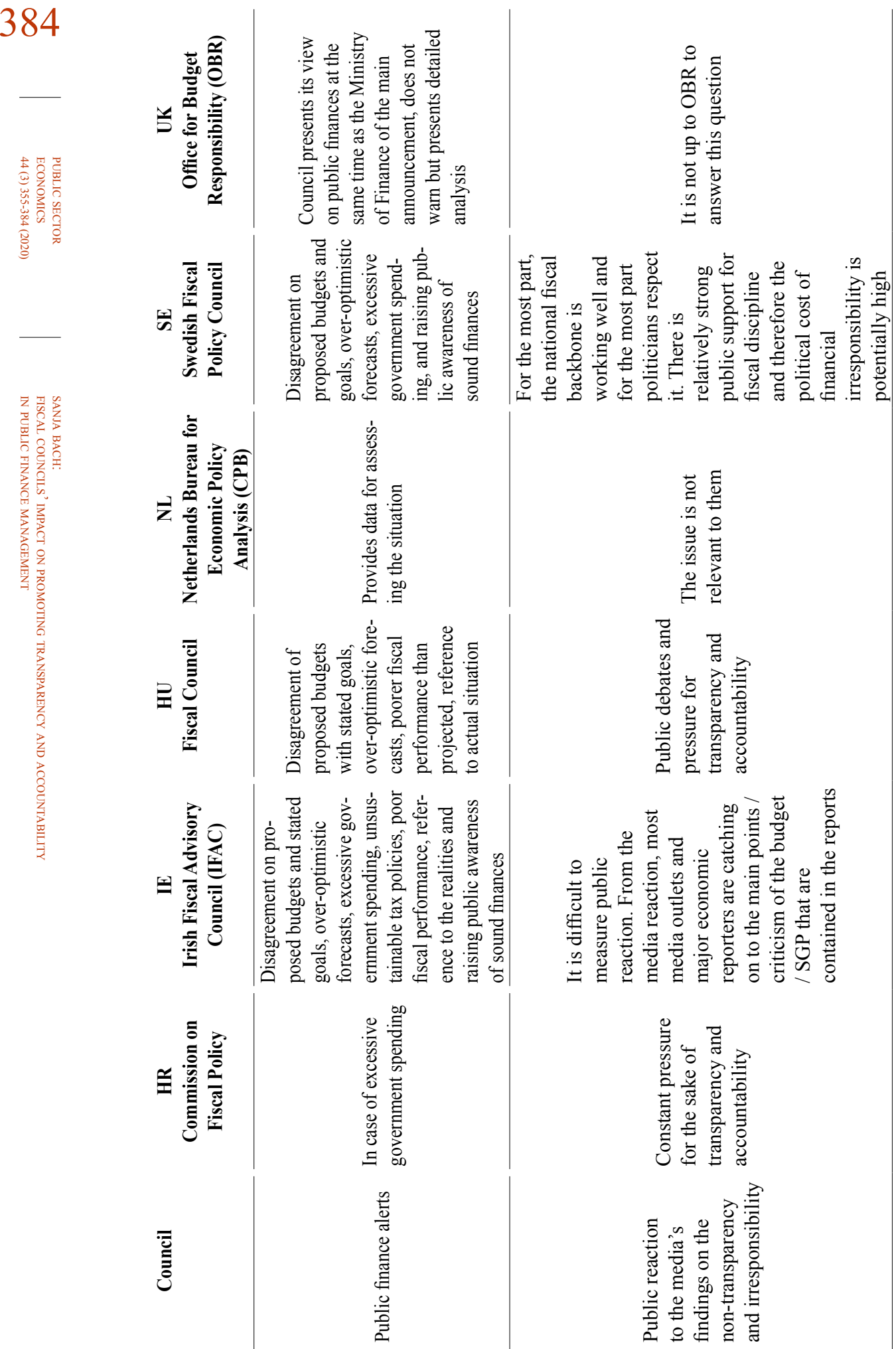